\title{
Preface to the special issue on international opportunities
}

\author{
Hamid Etemad ${ }^{1}$
}

Published online: 13 August 2015

(C) Springer Science+Business Media New York 2015

There is a broad consensus that opportunities are at the core of entrepreneurship and evolving into a complex and rich topic, encompassing different perspectives viewed from different lenses and assumptions, if not theories, over time. This special issue signifies the increasing importance of opportunities to, and characterizes the complexity of, the topic in international entrepreneurship. It is dedicated to exploring the issues of international opportunities in some depth, and it includes eight double-blind peerreviewed articles. The objective of this brief preface is threefold: expressing the journal gratitude to the team of guest editors, Professors Tuija Mainela, Per Servais, and Vesa Puhakka, for their dedication to developing the topic for more than a year and their diligent efforts in shaping the issue; thanking the authors and reviewers for undertaking the arduous, but rewarding, process of double-blind reviews and revisions; and, finally, providing a brief perspective on international opportunities in relation to basic conceptions of opportunity. The balance of this preface discusses the last objective.

The scholarly debate on whether opportunities are identified, or created, goes back to the origin of entrepreneurship and possibly to Jean Baptist Say (Say 1803). While the Kirznerian school of thought held that opportunities already existed and had to be identified (or found), the Schumpeterian school argued in favor of creating them. For international opportunities, this distinction is far from trivial, as they imply very different ex-ante conditions, different interim processes, and ex-post results. A muchused simple example of the Kirznerian opportunity is the case of "entrepreneurial arbitrage," where a Kirznerian entrepreneur comes across, or searches for, disparities and disequilibrium, which can assume many cases and shapes but share similar characteristics. For example, when the entrepreneur fulfills unmet demands (e.g., due to local shortages, higher prices) by bringing supplies from elsewhere (possibly at lower prices and from excess local supplies), he creates more value for buyers and suppliers and contributes to the economic efficiency of the sector, without undue disruptions, displacements, and harms to those concerned. As a result, the initial partial (or local) disequilibrium moves toward more general equilibria.

Hamid Etemad

hamid.etemad@mcgill.ca

$1 \quad$ McGill University, Montreal, QC, Canada 
International opportunity entails Kirznerian international entrepreneurs to "internationalize" the existing "opportunity" to arrive at its international counterpart, which may involve a search for and selection of market(s) experiencing similar local disequilibria and then "crossing borders" to supply and perform marketing and distribution in that (those) market(s), in order to realize the international opportunity(ties). The basic challenges here are to find the market(s), cross international boundaries and formulating proper procedures for ensuring desired outcomes, e.g., fulfilling unmet demands with a locally adapted approach at acceptable profits while delivering higher value than before. Practical experience indicates that when an opportunity exists in one local or national market (e.g., the home market), the more fragmented and larger international markets are highly likely to offer similar opportunities elsewhere. The entrepreneurial acts involved in realizing the international opportunity resemble those of international traders and brokers supplying from cheaper, and possibly overstocked, suppliers to locations with unmet demands. The international entrepreneur may also need to undertake some transformation of international supplies to meet the local requirements of the local opportunity (e.g., re-branding, re-packaging), but the essence, nature, and even the viability of the goods and services giving rise to the opportunity are not open to questioning and substantive change. Stated differently, the essence of goods and services involved in the opportunity is assumed to be universally applicable and optimal internationalization procedures would transform the once-local to international opportunities. The nature of such transformations generally is closer to those in international marketing as opposed to those in the international entrepreneurship domain. If we use profits, or value added, as an indicator, or the outcome, of opportunities, then suppliers selling internationally and buyers outsourcing internationally should be regarded as agents of international opportunities who would all benefit from exploiting the Kirznerian international opportunities by crossing some boundaries confining their past activities. Consequently, the state of local and international economies would experience growth (Solow 1956) and would be progressively driven toward higher-value equilibria.

In the Schumpeterian-type opportunity, however, the act of creating an opportunity is more complex than that of the Kirznerian type. The substance (e.g., goods, services, intellectual property) giving rise to an opportunity is usually embedded in a context and is generally context-dependent (or even path-dependent). In some cases, even the context needs to be created as well before the potential opportunity can be explored and realized. Logically, the internationalization of Schumpeterian opportunities would involve multiple contexts and possibly multiple time periods. For example, consider the case of music on demand, attributed to the efforts of Apple Computer Corporation. It involved not only the identification of potential customers eager to buy a single music tune at a reasonable price and a production system to provide it, but it also required the creation of a digital marketplace to complete the transaction. Apple's creation of iTunes, patterned after Shawn Fanning's file-sharing online technology, became a digital online marketplace, disrupting the routine practices of the prevailing music industry at the time and replacing both the music media - e.g., vinyl records, magnetic tapes, CDs - and their respective recording and playing devices at the same time. Similarly, the major components of the music distribution to and music consumption by consumers were also gradually replaced with digital recording and playing devices using small, portable, and online consumer electronic devices, based initially on MP3- 
type technologies. For acquiring and listening to a favorite tune, an MP3 device connected to a computer with online connection to Apple iTunes could download selected music tune(s). iTunes and similar programs provided a digital online marketplace for worldwide customers, who could purchase a single tune for $\$ 0.99$ and avoid paying $\$ 8$ to $\$ 18$ for a CD containing that particular tune. Similarly, musicians and suppliers of music, regardless of their time and location, could supply tunes to this marketplace by using the associated technological support system. As a result, the music industry as a whole underwent massive disruptive change: we hardly find a music store in advanced economies, nor do we find massive recording and listening devices, including large speakers and recording and playing equipments. Even most MP3 devices have become a part of smart cell phones now. Naturally, the Schumpeterian "creative destruction" attracted new musicians, created few new music producers and service providers, and displaced their older counterparts - not everyone benefited from the created opportunity in contrast to the case in Kirznerian opportunity.

More importantly, the above simple example points out that Schumpeterian international opportunity realization involves much more contextual (technical, legal, sociocultural, institutional) complexities than the mere identification, simple contextualization, and crossing of borders, as discussed earlier. It is likely to involve many challenges to many stakeholders, each forced to cross certain boundaries, mostly selfimposed due to constrained capabilities and resources, or set by the environment (or context), with asymmetric, and possibly uncertain, benefits and losses to the concerned agents. Those who stood to suffer from relative losses would logically exhibit resistance to adopting or supporting the "Schumpeterian opportunity" (which would be a loss maker for them), thus raising the cost of international realization to higher and riskier levels, requiring more capabilities, time, and resources than their counterparts in the Kirznerian opportunity realization system. A protective government, for example, may not allow for the adoption of supportive technologies, further contributing to the risks and costs of adoptions and reducing the diffusion pace of new creation locally, if not worldwide. From an entrepreneurial perspective, different levels of entrepreneurial initiative, orientation, and capabilities, including but not limited to risks, investments, and time, would be involved.

The above dichotomy is likely to be far simpler than the reality of what entrepreneurial firms would be experiencing in the international markets. As is well documented by the theory of international product life cycle (Vernon 1979; Vernon and Wells 1966), the international life cycle trajectory of international products would likely decline, be curtailed by local emulators, and even experience reversal as the product and its production system would evolve and move across international locations over time-e.g., consuming countries (initially importing) becoming producing countries and exporting the product after some elapsed time. This evolutionary pattern suggests that the initially simple support system behind the Kirznerian international opportunities is likely to involve research and development for creating the associated support system (e.g., for producing it locally and exporting eventually) and gravitating toward that of a Schumpeterian one). More complex opportunities associated with more complicated creative goods, services, and technologies - mostly of the Schumpeterian type - are also likely to benefit from entrepreneurial and corporate learning, spillovers (Romer 1994), customer feedback, and virtuous cycles of discovery and improvements (Zahra 2008) over time and move progressively toward exceedingly superior products 
(e.g., universal products) that would require no further change or little contextualization, if any. Theoretically then, the evolutionary process of opportunity internationalization of the Schumpeterian type would likely gravitate closer to internationalization transformations of the Kirznerian type. Therefore, the progressive generations of international opportunity realization systems, whether Kirznerian or Schumpeterian at the outset, would be expected to converge gradually and adopt hybrid processes, regardless of their local origins. Although this theoretical projection suggests a mixed, but converging, observed pattern across international markets over time, it does not shed light on the entrepreneurial seeds for raising trees that would mature to produce fruits - i.e., the opportunities - after some time, which would in turn gradually transcend contextualization and transformations for local environmental conditions. However, this special issue documents and presents some promising paths.

Finally, this special issue not only exposes the reader to a diverse and rich range of practical options and theoretical possibilities, its introductory paper challenges us to view the "crossing of the border" as the trigger point, or the seeds, of entrepreneurial opportunity trees that will eventually bear international fruits. This challenge and the special issue as a whole would merit serious scholarly attention.

\section{References}

Romer PM (1994) The origins of endogenous growth. J Econ Perspect V8(1):2-32

Say JB (2001 [1803]). A treatise on political economy; or the production distribution and consumption of wealth, trans. from the French, Batoche Books, Kitchener, Ontario, Canada

Solow R (1956) A contribution to the theory of economic growth. Q J Econ 70(1):65-94

Vernon R (1979) The product cycle hypothesis in a new international environment. Oxf Bull Econ Stat 41(4): 255-267

Vernon R, Wells LT (1966) International trade and international investment in the product life cycle. Q J Econ 81(2):190-207

Zahra SA (2008) The virtuous cycles of discovery and creation of entrepreneurial opportunities. Strateg Entrep J 2:243-257 